\title{
Latihan keterampilan sosial untuk meningkatkan kemampuan interaksi sosial pada pasien skizofrenia
}

May Lia Elfina, Universitas Muhammadiyah Malang, Malang, Indonesia

Korespondonesi:

May Lia Elfina, Universitas Muhammadiyah Malang, e-mail: mayliaelfina@gmail.com

\author{
Riwayat artikel \\ Naskah diterima: \\ $17 / 03 / 2019$ \\ Revisi diterima: \\ $03 / 05 / 2019$ \\ Naskah disetujui: \\ $15 / 06 / 2019$
}

\begin{abstract}
Abstrak
Subjek (L/29 tahun) mengalami halusinasi pendengaran hingga melakukan percobaan bunuh diri dan mengancam membunuh orang lain. Saat ini Subjek sering melamun, tidak mampu menjalin hubungan dekat dengan orang lain, malas, dan menghindar dari keramaian. Asesmen yang digunakan diantaranya wawancara, observasi, dan tes psikologi yang meliputi tes grafis (BAUM, DAP, dan HTP), WAIS, SSCT, dan WWQ. Berdasarkan hasil asesmen, Subjek didiagnosa mengalami gangguan skizofrenia 295.90 (sesuai dengan DSM V) dan mengalami masalah pada interaksi sosialnya. Intervensi menggunakan teknik psikoterapi yaitu latihan keterampilan sosial. Hasil intervensi menunjukkan bahwa interaksi sosial pada Subjek meningkat yang ditandai dengan adanya kemampuan Subjek untuk mengenal beberapa pasien di bangsal, selain itu Subjek mulai memiliki inisiatif untuk memberikan sapaan kepada orang-orang di sekitarnya. Subjek juga menunjukkan peningkatan yang cukup signifikan pada komunikasi non verbalnya (kontak mata, tersenyum, posisi tubuh yang tegap) ketika berkomunikasi dengan orang lain.

Kata kunci: Latihan keterampilan sosial, interaksi sosial, skizofrenia, intervensi
\end{abstract}

\section{Latar Belakang}

Skizofrenia adalah istilah yang digunakan untuk menggambarkan suatu gangguan psikiatrik yang ditandai dengan adanya perubahan pada persepsi, pikiran, afek, dan perilaku seseorang. Kesadaran yang jernih dan kemampuan intelektual biasanya tetap terpelihara, walaupun defisit kognitif tertentu dapat berkembang kemudian (Kaplan, Sadock, \& Grebb, 2010). Beberapa hal yang menjadi ciri utama gangguan skizofrenia adalah adanya kekacauan isi pikiran, waham, halusinasi auditorik, dan kekacauan perilaku (Maslim, 2001). Gangguan ini ditandai dengan 
gejala-gejala positif dan negatif. Gejala positif diantaranya yakni pembicaraan kacau, delusi, halusinasi, gangguan persepsi dan gangguan kognitif. Gejala negatif diantaranya adalah minat bicara yang berkurang, afek yang datar, hubungan interpersonal yang terganggu (Arif, 2006).

Tipe hebefrenik disebut juga sebagai tipe terdisorganisasi ditandai dengan regresi yang nyata ke perilaku primitif, onset awal biasanya pada usia sebelum 25 tahun. Pembicaraan dan cara bicaranya mirip dengan anak-anak, dan individu berjalan dengan langkah kaki kecil-kecil, afek yang datar dan inapropriate (Kaplan, 2010 \& Arif, 2006). Perilaku skizofrenia hebefrenik umumnya tidak bertanggungjawab, penderita terkadang menunjukkan sikap superior, pembicaraan yang dibesar-besarkan, dan terkadang mengulang-ulang beberapa kata atau frase dan terdapat kecenderungan untuk menyendiri (solitary).

Banyak hal yang dapat menjadi pencetus gangguan skizofrenia, termasuk dari lingkungan Subjek selain adanya stres, yakni faktor sosial ekonomi Subjek. Keadaan di lingkungan dengan ekonomi yang kurang menjadikan Subjek semakin stres. Semakin tinggi resiko stres pada lingkungan dan keluarga Subjek dengan skizofrenia akan meningkatkan reaktivitas emosi pada kehidupan sehari-hari dan hal tersebut akan memberikan dampak pada cara seseorang melakukan interaksi dengan lingkungan sosialnya (Myin-Germeys, van Os, Schwartz, Stone, \& Delespaul, 2001).

Kejadian traumatik yang dapat menjadi pemicu munculnya halusinasi untuk pertama kali selain stres menahun adalah saat Subjek berada di pondok pesantren dan Subjek dibentak anak kyai serta di olok-olok oleh teman Subjek. Saat itu siang hari menjelang sholat jumat, Subjek menyalakan tape yang berisi ayat-ayat alquran di mushollah. Tidak disadari, Subjek menyalakan suara tersebut dengan suara yang sangat keras dan menyalakan suara terlalu awal dari jam yang sudah ditentukan. Subjek merasa trauma dengan bentakan anak kyai tersebut. Subjek kecewa dengan dirinya sendiri mengingat Subjek sangat patuh kepada kyai dan keluarganya, sehingga Subjek merasa bersalah.

Kepribadian Subjek yang terlalu tertutup membuatnya memikirkan hal tersebut sebagai kejadian yang luar biasa dan traumatik. Subjek akhirnya dibawa pulang oleh pamannya setelah mendapatkan laporan bahwa Subjek sering berbicara sendiri di pondok pesantren. Selain itu perilaku yang ditunjukkan mulai mengarah kepada mannerism (tidak bertanggung jawab), sebagai contoh tidak menjaga kebersihan diri dan sering marah karena merasa mendengar suara-suara di telinganya tanpa adanya wujud yang nyata. Subjek pulang dan membantu ayahnya mengerjakan sawah. Namun demikian Subjek mengeluh dan semakin terlihat sedih karena merasa gagal mempelajari ilmu di pondok pesantren terlebih sudah membuat kecewa kyai dan keluarganya. Kejadian traumatik di atas dapat menjadi penyebab skizofrenia.

Hasil penelitian mengungkapkan bahwa kejadian traumatik yakni tidak tercapainya cita-cita, kehilangan orang yang dicintai, pola asuh yang salah (terlalu otoiter/terlalu neglected), serta mengalami kekerasan akan memicu gangguan skizofrenia (Rus-Calafell, Gutiérrez-Maldonado, Ribas-Sabaté, \& Lemos-Giráldez, 2014). Pada saat di rumah, Subjek tinggal dengan ayah dan ibunya. Ayah Subjek adalah seseorang yang sangat sabar, sehingga wujud otoritas dari seorang ayah kurang dirasakan oleh Subjek. Hal ini yang membuat Subjek berani melawan ayahnya ketika marah dan mendengar suara-suara bisikan.

Tingkah laku maladaptif adalah hasil dari kegagalan belajar untuk melakukan respon yang tepat. Defisit perilaku yang disebabkan dari kegagalan untuk belajar dan perilaku maladaptif menyimpang yang merupakan akibat dari mempelajari hal yang tidak sesuai (Kaplan et al., 2010). Kesalahan belajar yang menghasilkan perilaku maladaptif dapat diselesaikan dengan berbagai cara, salah satunya yakni pemberian latihan keterampilan sosial. Seseorang melakukan perilaku maladaptif dikarenakan kurang adanya penghargaan (reward) yang memadai dari lingkungan, dimungkinkan juga karena tidak adanya keterampilan tertentu yang dimilikinya (Alwisol, 2011). Pembiaran yang dilakukan oleh keluarga dan lingkungan Subjek mengakibatkan 
terkondisinya perilaku maladaptif Subjek, yakni interaksi sosial yang sangat rendah, bahkan semakin memburuk dan menjadi perilaku yang dianggap Subjek benar.

Saat ini, $\mathrm{P}$ cenderung menghindar dari keramaian, tidak memiliki teman dekat, kurang mampu memberi tanggapan ketika pasien atau orang lain mengajaknya berbicara, tidak menampakkan kehangatan. Hal tersebut menunjukkan bahawa P kurang memiliki kemampuan interaksi sosial yang baik, bahkan dapat dikatakan menghindari untuk melakukan interaksi dengan orang lain. Oleh karena itu perlu adanya latihan keterampilan dalam melakukan interaksi sosial sehingga $\mathrm{P}$ mampu bersosialisasi dengan baik dan mengurangi perilaku menyendiri serta melamun.

Latihan keterampilan sosial (Social Skill Training/SST) dipilih sebagai intervensi pada Subjek karena masalah utama yang muncul saat ini adalah tentang interaksi sosial Subjek. Latihan keterampilan sosial diberikan pada pasien yang memiliki kekurangan dalam kemampuan melakukan interaksi dengan orang lain. SST dapat digunakan dengan tujuan meningkatkan fungsi sosial, kognisi dan kompetensi sosial, termasuk meningkatkan interaksi sosial pada penderita skizofrenia (Rus-Calafell et al., 2014). Dengan demikian, diharapkan pemberian pelatihan keterampilan sosial dapat meningkatkan interaksi sosial pada Subjek dengan skizofrenia. Seseorang tidak mendapatkan reinforcement dari lingkungan akibat kurangnya keterampilan pada dirinya sehingga agar Subjek mendapatkan reinforcement dari lingkungannya, perlu untuk diberikan pelatihan keterampilan sosial (Alwisol, 2011).

\section{Metode Asesmen}

Metode asesmen yang digunakan adalah observasi, wawancara, studi dokumentasi, serta tes psikologi. Metode ini digunakan untuk menentukan diagnosa gangguan pada Subjek. Wawancara juga dilakukan pada keluarga dan perawat ruangan untuk mendapatkan data tambahan secara mendalam berkaitan dengan riwayat perjalanan gangguan yang dialami oleh Subjek. Observasi juga dilakukan untuk mengetahui penampilan Subjek, perilaku, afek, gangguan perseptual, orientasi dan kesadaran Subjek.

Tes psikologis yang digunakan mencakup tes intelegensi dan kepribadian yaitu tes WAIS (Weschler Adult Intelligence Scale), grafis (BAUM, DAP dan HTP), SSCT, dan Woodworth's Questionnaire (WWQ). Tes WAIS digunakan untuk mengetahui tingkat intelegensi Subjek dan beberapa gejala klinis yang dapat diungkapkan melalui tes WAIS. Tes grafis digunakan untuk mengetahui ciri kepribadian Subjek secara lebih mendalam dan komprehensif. Tes SSCT digunakan untuk mengetahui area konflik yang dialami oleh Subjek. Selanjutnya untuk tes WWQ digunakan untk mengetahui tendensi gangguan dan permasalahan yang dialami oleh Subjek sebagai crosscheck kondisi Subjek saat ini.

\section{Presentasi Kasus}

Subjek P adalah laki-laki dengan gangguan skizofrenia berusia 29 tahun dan belum menikah. Onset pada Subjek mulai muncul saat Subjek berusia 20 tahun atau pada saat dewasa awal. Subjek telah melakukan rawat inap di RSJ Lawang sebanyak tiga kali. Subjek bekerja sebagai petani. Subjek bersekolah hanya sampai lulus SD. Setelah lulus SD Subjek melanjutkan pendidikan ke pondok pesantren di Kediri untuk memperdalam agama. Subjek tinggal bersama kedua orang tuanya. Berdasarkan penuturan keluarga dan para tetangga, Subjek merupakan anak yang sangat sopan, cukup sering menyendiri, namun turut berpartisipasi jika terdapat kegiatan di lingkungannya.

Sekitar Bulan Februari 2014, Subjek masuk rumah sakit jiwa untuk pertamakalinya. Subjek merusak barang-barang di rumah sambil marah-marah. Subjek pernah sakit pada saat di Pondok Pesantren, sekitar tahun 2009. Menurut keluarga, Subjek mulai marah-marah dan berbicara sendiri namun hanya berobat ke Puskesmas dan mendapatkan obat penenang. Pada 
saat itu (tahun 2013) Subjek terlambat minum obat atau putus obat selama tiga bulan. Hal ini yang menyebabkan Subjek kambuh pada tahun 2014.

Pada tahun 2014, keluhan yang dialami Subjek adalah merasa makanan yang dirasakannya terasa basi sehingga tidak mau makan, mendengar suara "pukul ibu", perintah sembunyi di sumur karena merasa ada yang akan membunuhnya dan agar malaikat pencabut nyawa tidak mengetahui Subjek dan ketika tidur merasa melihat malaikat pencabut nyawa. Subjek mengaku pernah memukul ayah, bicara dengan hewan, dan membakar kandang sapi miliki ayahnya. Pada malam hari, ketika suara-suara halusinasi muncul, Subjek berdiam diri di kamar dan memutar lagu di radio dengan volume suara sangat tinggi. Keluarga Subjek mengakui bahwa menghentikan pengobatan dari puskesmas, dikarenakan keluarga khawatir dengan kesehatan jantung Subjek dan membuat Subjek menjadi sering sakit perut.

Subjek masuk Rumah Sakit Jiwa Lawang untuk pertama kalinya pada tanggal 19 Februari 2014 dengan diagnosa awal skizofrenia paranoid. Didapatkan pula informasi bahwa ibu Subjek memiliki gangguan jiwa sama seperti yang dialami oleh Subjek. Subjek keluar dari rumah sakit (setelah MRS/Masuk Rumah Sakit yang pertama) pada tanggal 7 Maret 2014 setelah kurang lebih dirawat di Ruang Parkit selama 1 bulan.

Pada tahun 2015 bulan April tanggal 11, Subjek masuk ke rumah sakit untuk kedua kalinya. Subjek mendapatkan diagnosa F.20.23 (skizofrenia katatonik berulang) dan Z.91.1 (ketidakpatuhan dalam minum obat). Keluhan Subjek pada tahun ini adalah marah-marah dan membanting perabot rumah. Subjek juga sempat memukul saudaranya. Satu bulan penuh di kamar mengurung diri dan tidak mau keluar rumah. Setiap malam Subjek susah untuk tidur, sehingga hanya mondar-mandir di dalam rumah. Subjek relaps akibat putus obat selama tiga bulan. MRS kedua ini, Subjek dirawat di Ruang Parkit selama 2 bulan dan keluar dari rumah sakit pada tanggal 1 Juni 2015.

Subjek kembali mengalami relaps pada tanggal 25 Agustus 2018. Pada saat awal datang Subjek dalam kondisi tenang dan cukup kooperatif. Tercatat dari pertama kali masuk Rumah sakit, Subjek tergolong pasien dengan resiko bunuh diri yang cukup tinggi. Pada tahun 2018, Subjek terdiagnosa sebagai F.20.13/ Skizofrenia Hebefrenik episode berulang dengan gangguan penyerta Z.91.1/ketidakpatuhan dalam minum obat. Subjek dibawa ke rumah sakit dengan keluhan tidak minum obat selama dua tahun terakhir, sudah mengalami kambuh selama tiga bulan terakhir. Subjek mendengar suara laki-laki dan perempuan untuk melakukan pembunuhan, Subjek juga mengaku bisa terbang ke bulan dengan sayapnya.

Orientasi waktu dan tempat Subjek saat ini cukup baik, Subjek memahami tanggal, jam, dan tempat dimana Subjek berada. Orientasi terhadap orang juga cukup baik, Subjek mampu menempatkan diri dalam menghadapi pasien lain, dokter, perawat, dan terapis. Subjek memiliki insight terhadap gangguannya, dalam artian Subjek memiliki pemahaman bahwa dirinya memiliki gangguan, Subjek juga memahami penyebabnya yakni halusinasi auditorik yang dialaminya semenjak tahun 2009, Subjek juga sadar bahwa Subjek harus melakukan pengobatan, baik secara biologis (obat/farmako), maupun psikologis (terapi), namun Subjek terkadang lalai dengan kewajiban minum obatnya yang mengakibatkan Subjek relaps. Subjek pun menyadari kekambuhan gangguannya adalah akibat dari putus obat yang dilakukannya selama 2 tahun terakhir sehingga Subjek mengalami halusinasi kembali dan berakibat pada emosinya yang meledak, yakni marah-marah kepada ayahnya maupun orang-orang di sekitarnya.

Dinamika terbentuknya gangguan skizofrenia pada Subjek dapat dijelaskan melalui model diathesis stress. Model ini menjelaskan bahwa seseorang mungkin memiliki suatu kerentanan spesifik (diathesis) yang jika dikenai oleh suatu pengaruh lingkungan yang menimbulkan stres, memungkinkan untuk mengembangkan gejala skizofrenia dan dapat dijelaskan melalui kerentanan genetis, psikologis, dan lingkungan sosial (Kaplan et al., 2010). Model diathesis menjadi relevan dengan munculnya gangguan pada Subjek P. Subjek memiliki kerantanan secara 
genetis karena ibu Subjek mengalami gangguan yang sama, kemudian faktor psikologis Subjek yakni kepribadian menghindar, perasaan yang mudah kecewa pada diri sendiri, inferior, merasa tidak berdaya dengan rasa bersalah, melarikan diri dari realitas, dan rasa takut yang besar. Faktor stressor lingkungan yang dialami oleh Subjek adalah kegagalan menggapai cita-cita, serta figur otoritas yang hilang.

Subjek cenderung menghindari keramaian, lebih senang menyendiri daripada melakukan interaksi dengan pasien lainnya. Kebiasaan Subjek menyendiri, tanpa adanya teguran dan modelling dari orang tua untuk melakukan interaksi sosial, membuat Subjek semakin nyaman dengan apa yang dilakukannya, yakni menyendiri, melamun, dan tidak menyapa ataupun berkomunikasi dengan orang-orang di sekitarnya. Pembiaran tersebut terjadi terus menerus sehingga terkondisi pada Subjek untuk tidak melakukan interaksi sosial. Teori yang dapat menjelaksan tentang hal ini adalah teori perilaku operan conditioning B.F. Skinner.

Hasil yang sejalan ditemukan pada tes psikologi yang dilakukan oleh Subjek. Berkaitan dengan interpretasi WAIS, berdasarkan perbandingan verbal IQ yang lebih tinggi daripada performance IQ, diindikasikan bahwa Subjek memiliki kemampuan yang cukup dalam pehamanan informasi, namun rendah dalam hal hubungan interpersonal. Hal ini terbukti dengan pemahaman Subjek ketika berkomunikasi dengan terapis dengan cukup baik, namun demikian sangat kurang dalam menjalin komunikasi maupun interaksi dengan pasien lainnya.

Selain itu, berdasarkan hasil tes grafis dan SSCT, Subjek tergambar sebagai individu yang tertutup, pendiam, gelisah ketika menghadapi masalah, tendensi schizoid, serta kurang merasakan figur otoritas ayah dan merasa dikucilkan dari keluarganya. Secara sosial, Subjek sebenarnya cukup mampu mengartikan situasi di sekitarnya, namun kurang ada inisiatif dalam melakukan tindakan untuk mengeksplorasi lingkungannya. Hal ini terlihat melalui hasil wawancara bahwa Subjek memiliki hubungan yang cukup baik dengan pasien lain/tidak menunjukkan adanya agresi, namun sering menghindar jika didekati oleh pasien lain dan cenderung melamun. Selain itu sejalan dengan hasil grafis yang diperoleh, berdasarkan observasi, Subjek merupakan seseorang yang tertutup, dan pendiam.

Berdasarkan WWQ, Subjek juga tergambar memiliki paranoid tendence, adanya penarikan diri, dan kurang adanya hubungan yang hangat dengan orang lain. Selain itu hal yang mencolok dari hasil tes WWQ adalah deprivasive hypochondrial, dimana Subjek seringkali mengeluh sakit secara fisik yang menyebabkan Subjek menjadi lebih buruk. Hal ini jika tidak dialihkan kepada hal lainnya, maka memperparah symptom Subjek terkait dengan kurangnya interaksi sosial karena Subjek lebih memilih tidur, diam, dan beristirahat.

Teori perilaku dipilih sebagai landasan teori untuk pemilihan terapi dikarenakan pada kondisi Subjek saat ini sedang mengalami perilaku maladaptif yakni interaksi sosial Subjek yang sangat rendah. Terapi perilaku digunakan untuk mendorong Subjek melakukan hal yang dituju dengan memberikan pujian dan hadiah, sehingga frekuensi perilaku maladaptif dapat berkurang (Kaplan et al., 2010). Teori yang dijelaskan oleh B.F Skinner yakni mengenai adanya reinforcement. Teori operant conditioning atau instrumental conditioning menjadikan reinforcer tidak diasosiasikan dengan stimulus yang dikondisikan, tetapi diasosiasikan dengan respon karena respon itu sendiri beroperasi memberi reinforcement sehingga disebut dengan tingkah laku operan. Tingkah laku operan mungkin juga belum dimiliki oleh individu tetapi individu tersebut akan melakukannya karena adanya penguat (reinforcement) tidak seperti operan klasik dimana tingkah laku adalah hasil tingkah laku yang refleks, sehingga tingkah laku operan lebih fleksibel dibandingkan tingkah laku klasik/refleks. Jika tingkah laku operan diikuti dengan penyajian stimulus yang menguatkan, maka kekuatan tingkah laku tersebut akan bertambah dan sering dilakukan (Olson \& Hergenhahn, 2011).

Kegagalan tercapainya respon yang adaptif, dapat juga diakibatkan oleh adanya pembiaran terhadap respon maladaptif ketika suatu stimulus hadir. Proses belajar yang salah dan tidak 
adanya modelling tentang perilaku yang benar, serta tidak adanya masukan dari lingkungan tentang perilaku adaptif mengakibatkan perilaku maladaptif yang ada saat ini terkondisi dan menjadi habituasi sehingga dianggap sebagai perilaku yang benar orang seseorang.

Dalam kasus ini, Subjek memiliki perilaku interaksi sosial yang kurang, kemudian orang tua yang membiarkan perilaku tersebut terus menerus terjadi dan tidak adanya modelling yang benar sehingga mengakibatkan perilaku maladaptif menjadi habituasi dan terkondisi semakin memburuk. Subjek memiliki interkasi sosial yang minim, kemudian terjadi pembiaran secara terus menerus dari orang tua maupun lingkungan Subjek yang mengakibatkan respon negatif berupa perilaku maladaptif (interaksi sosial yang rendah) menjadi suatu habituasi dan terkondisi semakin memburuk, dengan ciri Subjek menghindar ketika orang lain mendatanginya, Subjek tidak memberikan respon ketika ditanya dan disapa oleh orang lain, terlebih ketika ditanya tentang kondisi Subjek maupun saat berkenalan.

Faktor premorbid pada Subjek yang menambah kerantanan psikologis yakni berkaitan dengan kepribadiannya. Kebiasaan Subjek yang selalu terlihat yakni menutup diri, menarik diri, susah untuk berkomunikasi dan menjalin hubungan dengan orang lain. Subjek merasa bahwa Subjek ingin selalu sendiri dan tidak mau diganggu oleh orang lain. Subjek hampir tidak pernah bertegur sapa dengan orang lain. Subjek lebih suka melamun, berdiam diri, dan tidur dibandingkan menjalin hubungan dengan orang lain. Inistiatif Subjek dalam menyapa dan untuk peka terhadap sekelilingnya masih kurang.

\section{Diagnosis dan Prognosis}

\section{Diagnosis}

Berdasarkan hasil asesmen dan uraian kasus di atas, merujuk pada Diagnostic and Statistical Manual of Mental Disorder Fifth Edition (DSM-V) (APA, 2013) maka dapat ditegakkan diagnosis pada Subjek yakni: gangguan skizofrenia code 295.90 (F20.9). Gejala gangguan skizofrenia pada Subjek yakni adanya delusi dan halusinasi serta berkembangnya simptom negatif, dengan permasalahan rendahnya kemampuan interaksi sosial.

\section{Prognosis}

Prognosis pada Subjek adalah baik. Hal ini didukung oleh Subjek memiliki insight yang baik terhadap gangguannya, serta orientasi yang baik pula, selain itu Subjek memiliki motivasi yang cukup tinggi untuk mempelajari dan mengaplikasikan materi dan pelatihan yang diberikan oleh terapis. Keluarga Subjek juga cukup terbuka dengan proses terapi dan berusaha untuk merubah kebiasaan Subjek yang hanya berdiam diri di rumah, dan mengajaknya untuk berinteraksi dengan tetangga.

\section{Intervensi}

Intervensi yang digunakan pada kasus ini adalah Latihan keterampilan sosial, dimana psikoterapi yang digunakan adalah psikoterapi yang berorientasi pada perilaku. Seseorang akan diberikan pembelajaran tantang proses dan cara fungsional dalam melakukan interaksi dengan orang lain (Varcarolis, Carson, \& Shoemaker, 2006). Dengan melakukan latihan keterampilan sosial, maka seseorang lebih mampu melakukan interaksi dengan orang lain dengan memberikan respon positif terhadap lingkungan dan mengurangi respon negatif yang ada pada diri orang tersebut.

Keterampilan sosial adalah segala kemampuan yang menunjang seseorang dalam melakukan interaksi dan berkomunikasi dengan orang lain dengan beberapa kemampuan spesifik yang akan membentuk perilaku sosial individu, kemampuan komunikasi ini dapat berbentuk kontak mata, mengucapkan terimakasih, dan meminta pertolongan (Little, Swangler, \& Akin-little, 2017). Tujuan latihan keterampilan sosial adalah meningkatkan kemampuan sosial pada individu dengan memfokuskan intervensi pada interaksi individu dengan individu lainnya 
(Kneisl \& Trigoboff, 2004). Latihan keterampilan sosial bertujuan untuk meningkatkan kemampuan seseorang memberikan respon saat berinteraksi sosial, secara non verbal (kontak mata, tersenyum, posisi tubuh tegap) dan verbal (menjawab pertanyaan, berkenalan), mampu memulai interaksi, dan mampu mempertahankan interaksi yang telah terjalin.

Pelaksanaan latihan keterampilan sosial dilakukan dengan empat tahap, yaitu; 1) Modelling, adalah terapi terapis memberikan contoh keterampilan yang akan diajarkan kepada Subjek; 2) Role playing, yaitu tahap Subjek mendapatkan kesempatan untuk menirukan demonstrasi yang dilakukan oleh terapis; 3) Performance feedback, yaitu terapis akan memberikan umpan balik tentang apa yang sudah dilakukan oleh Subjek, umpan balik dilakukan segera setelah Subjek melakukan tugasnya; 4) Transfer training, yaitu tahap ketika pelajaran yang sudah diberikan oleh terapis dapat dilakukan dan diaplikasikan pada kehidupan Subjek sehari-hari (Prawitasari et al., 2002).

Latihan keterampilan sosial dipilih sebagai intervensi dalam kasus ini karena merupakan masalah saat ini yang dialami oleh Subjek dan urgent untuk diselesaikan. Ketika Subjek memiliki interaksi yang cukup baik dengan orang lain, maka Subjek mampu menyalurkan pendapat, emosi, dan perasaan dengan adaptif pula. Dengan adanya latihan dan pembelajaran keterampilan sosial, diharapkan Subjek mampu melakukan interaksi sosial dengan lebih baik, baik pada saat di rumah sakit, maupun setelah kepulangan Subjek di rumah.

Komponen keterampilan sosial bagi skizofrenia terdiri dari expressive skills, receptive skills (kemampuan merespon situasi sosial), conversational skills (kemampuan berbicara dengan orang lain), social perception skills (kemampuan melakukan persepsi atas situasi sosial), serta kemampuan tambahan untuk situasi yang beramasalah, seperti asertif, heterososial, kemandirian, dan keteraturan minum obat (Bellack, Mueser, Gingerich, \& Agresta, 2013). Namun dalam kasus ini intervensi difokuskan pada expressive skills Subjek yakni meliputi kemampuan verbal (berkenalan, menyapa terlebih dahulu, memiliki teman dekat) dan non verbal (kontak mata, ekspresi wajah, dan postur badan).

Sebelum dilakukan intervensi terhadap Subjek, terapis memberikan informed consent sebagai kontrak Subjek dan keluarga untuk dilakukannya intervensi dan mengikuti proses intervensi hingga selesai dan terjalin hubungan yang kondusif untuk melakukan intervensi selanjutnya. Selain itu, terapis memberikan pengarahan terhadap keluarga terkait dengan pentingnya konsumsi obat rutin dan kontrol rutin dan terapis memberikan penjelasan bahwa halusinasi seringkali muncul ketika Subjek tidak melakukan aktivitas sehingga Subjek dibiasakan untuk menjadi sibuk dalam beraktivitas salah satunya dengan melakukan interaksi dengan orang lain. Terapis mengajak keluarga untuk berkomitmen dan mendukung Subjek dalam menjalankan intervensi serta selalu melibatkan Subjek dalam pembicaraan atau pengambilan keputusan yang berkaitan dengan diri Subjek, serta memberikan contoh tentang interkasi sosial yang baik dan berkelanjutan.

Target latihan keterampilan sosial pada Subjek adalah megajak Subjek agar mau melakukan interaksi sosial, meliputi komunikasi secara verbal dan non verbal. Komunikasi non verbal antara lain mengawali senyum kepada orang lain, melakukan kontak mata dengan lawan bicara, membuat posisi tubuh yang tegap jika sedang berbicara. Sedangkan komunikasi verbal antara lain memulai pembicaraan dengan orang lain, mengenal pasien lain di bangsal, dan memiliki teman dekat untuk berbagi cerita. Berikut adalah tahapan latihan keterampilan sosial (Renidayati, Nurjanah, Rosiana, \& Pinilih, 2015).

Sesi Satu: Orientasi dan pengkajian keterampilan sosial. Subjek diajarkan tentang pengertian komunikasi secara verbal dan non verbal meskipun selalu diberikan stimulus terlebih dahulu untuk mengingat jawabannya. Terapis meyakinkan bahwa komunikasi non verbal sangat penting dalam melakukan interaksi sosial sehingga Subjek mau menerapkan dalam kehidupan sehari-hari. Subjek menerapkan keterampilan yang telah diajarkan, kepada setiap lawan bicara 
yang ada di depannya, dan terapis mengetahui progressnya. Setiap keterampilan pada sesi II akan diulang pada sesi-sesi berikutnya sehingga terpola latihan yang terus menerus. Subjek juga mempersiapkan diri untuk melakukan sesi berikutnya sehingga pertemuan selanjutnya Subjek sudah memiliki gambaran atas apa yang akan dilakukan. Pada akhir sesi ini, Subjek mampu mempraktikkan komunikasi verbal dan non verbal serta mengetahui pengertian, manfaat, jenis dari komunikasi dari interaksi sosial, serta mengetahui tahapan sesi selanjutnya. Pada sesi ini Subjek merasa biasa saja, tidak pula menunjukkan ekspresi senang, namun demikian Subjek berani mempraktikkan keterampilan yang diajarkan dengan cukup baik.

Sesi Dua: Melatih kemampuan berkomunikasi. Subjek diminta untuk menyebutkan kembali manfaat melakukan interaksi sosial. Selain itu terapis mengajarkan tentang komunikasi secara verbal dan non verbal dengan metode modeling, roleplay, feedback, dan transfer training. Subjek bisa menirukan dengan cukup baik meskipun perlu diulang berberapa kali. Pada sesi II ini, Subjek masih kurang menunjukkan antusias yang signifikan, namun Subjek tetap fokus ketika diberikan intervensi oleh terapis. Pada sesi ini target terpenuhi, yakni Subjek mampu menirukan komunikasi secara verbal dan non-verbal.

Sesi Tiga: Melatih kemampuan untuk menjalin persahabatan. Pada sesi ini, terapis mengajarkan cara menyapa, dan memulai berkenalan. Subjek menirukan apa yang diajarkan oleh terapis dengan baik. Tidak lupa, terapis memberikan feedback atas apa yang telah dilakukan oleh Subjek. Akhirnya, Subjek mampu menegur dan berkenalan dengan orang lain dengan mengulang kembali materi sesi II yakni tentang komunikasi non verbal. Pada sesi ini, Subjek mengungkapkan alasannya tidak melakukan interaksi dengan orang lain karena Subjek berfikir akan mengganggu orang lain dan dimarahi karena menegur dan mengajak orang lain berbicara. Pikiran tersebut diluruskan oleh terapis bahwa tidak semua orang akan memberikan reaksi yang sama ketika disapa oleh orang lain. Terapis juga sempat mencontohkan secara langsung dengan mendorong Subjek untuk mencobanya sekali lagi dengan pasien yang telah ditunjuk oleh terapis untuk Subjek mencoba berkenalan. Setelah mencoba dan berhasil Subjek mengungkapkan bahwa saat ini sudah berkurang rasa takutnya untuk mengawali percakapan. Perasaan Subjek pada sesi ini cukup senang, terlihat dari senyuman yang lebih intens diberikan oleh Subjek kepada terapis. Akhir dari sesi ini, Subjek mendapatkan tugas untuk berkenalan dengan 10 pasien di bangsalnya dan akan dibahas pada sesi berikutnya.

Sesi Empat: Evaluasi dari Subjek.Pada sesi ini, Subjek diminta untuk menceritakan kembali tentang tugas berkenalan dengan pasien lain di bangsalnya. Subjek mampu menyebutkan 10 nama pasien lain, namun demikian masih belum mampu melakukan inisiatif dalam berkenalan, dan menunggu teman lain yang menegur Subjek terlebih dahulu.

Sesi Lima: Evaluasi. Subjek sendiri mengetahui kemampuannya dalam memulai interaksi untuk menjalin persahabatan. Saat ini Subjek memiliki satu teman yang paling dipercaya dan dekat dengan Subjek, sehingga Subjek dapat berbagi cerita dengannya. Subjek mengetahui target yang terpenuhi dan tidak terpenuhi dari intervensi yang telah dilakukan. Pada sesi ini, Subjek mampu melatih mengemukakan pendapat tentang manfaat kegiatan yang telah dilakukan baik secara eksplisit (lebih bisa interaksi, memiliki sahabat, memiliki teman) maupun implisit (lega, lebih percaya dengan orang lain). Subjek mendapatkan saran dan keterampilan lainnya sebagai intervensi lanjutan dalam meningkatkan interaksi sosialnya (dapat dilihat dari target yang tercapai dan belum tercapai)

Sesi Enam: Follow up. Subjek mengalami perubahan perilaku interaksi sosial yang ditunjukkan dengan peristiwa bahwa Subjek berani menyapa terapis dengan inisiatifnya sendiri selain itu berdasarkan observasi yang dilakukan satu minggu setelah terminasi, Subjek mulai bergabung dengan pasien lainnya dan sesekali tersenyum jika terdapat pasien lain yang melakukan hal yang lucu. 


\section{Hasil dan Pembahasan}

\section{Hasil}

Subjek mengikuti proses intervensi dengan baik, meskipun pada awalnya, Subjek kurang memiliki antusias dalam melakukan intervensi. Hasil intervensi latihan keterampilan sosial dapat dilihat pada Tabel 1.

Berdasarkan hasil intervensi enam target pada latihan keterampilan sosial ini, lima diantaranya dapat mencapai target. Target yang dicapai oleh Subjek antara lain komunikasi non verbal (senyum, kontak mata, dan sikap tubuh yang tegap), selain itu target komunikasi verbal yakni mengenal pasien lain di bangsal, memiliki teman dekat, dan memulai interaksi. Selain itu, terapis juga memberikan edukasi kepada keluarga Subjek terkait dengan masalah putus obat Subjek sebagai stresso MRS ke 2 dan ke 3. Terapis memberikan penjelasan tentang pentingnya bagi Subjek untuk menjaga keteraturan minum obat dengan melakukan diskusi dengan keluarga subjek.

Tabel 1. Ketercapaian Target Intervensi Latihan Keterampilan Sosial

\begin{tabular}{|c|c|c|c|c|c|c|c|c|c|}
\hline Aspek & $\begin{array}{l}\text { Sebelum } \\
\text { intervensi }\end{array}$ & 1 & 2 & 3 & 4 & 5 & 6 & $\begin{array}{l}\text { Sesudah } \\
\text { intervensi }\end{array}$ & Target \\
\hline Senyum & $\begin{array}{ll}\text { Tidak } & \text { mau } \\
\text { mengawali } & \\
\text { senyum } & \mathrm{kpd} \\
\text { orang lain } & \end{array}$ & 0 & 0 & 1 & 1 & 1 & 1 & $\begin{array}{l}\text { Mau mengawali } \\
\text { senyum kpd orang } \\
\text { lain }\end{array}$ & Tercapai \\
\hline $\begin{array}{l}\text { Kontak } \\
\text { mata }\end{array}$ & $\begin{array}{l}\text { Tidak mau } \\
\text { membuat kontak } \\
\text { mata yang intens } \\
\text { dg lawan bicara }\end{array}$ & 0 & 1 & 1 & 1 & 1 & 1 & $\begin{array}{l}\text { Mampu membuat } \\
\text { kontak mata dg } \\
\text { lawan bicara }\end{array}$ & Tercapai \\
\hline $\begin{array}{l}\text { Posisi } \\
\text { tubuh }\end{array}$ & $\begin{array}{l}\text { Posisi tubuh } \\
\text { membungkuk } \\
\text { dan menghadap } \\
\text { ke bawah, } \\
\text { terkadang pergi } \\
\text { meninggalkan } \\
\text { lawan bicara }\end{array}$ & 0 & 1 & 1 & 1 & 1 & 1 & $\begin{array}{lr}\text { Posisi } & \text { tubuh } \\
\text { tegap dan tidak } \\
\text { menunduk, } \\
\text { serta mampu } \\
\text { bertahan di } \\
\text { tengah keramaian } \\
\text { pasien lain yg } \\
\text { sedang berbicara }\end{array}$ & Tercapai \\
\hline $\begin{array}{l}\text { Mengenal } \\
\text { pasien } \\
\text { lain }\end{array}$ & $\begin{array}{l}\text { Tidak mengetahui } \\
\text { nama-nama } \\
\text { pasien lain }\end{array}$ & 0 & 0 & 0 & 1 & 1 & 1 & $\begin{array}{l}\text { Mengetahui } 10 \\
\text { dari jumlah total } \\
\text { pasien di bangsal }\end{array}$ & Tercapai \\
\hline $\begin{array}{l}\text { Memiliki } \\
\text { teman } \\
\text { dekat }\end{array}$ & $\begin{array}{lr}\text { Tidak } & \text { memiliki } \\
\text { teman } & \text { dekat } \\
\text { untuk } & \text { berbagi } \\
\text { bercerita } & \end{array}$ & 0 & 0 & 0 & 0 & 1 & 1 & $\begin{array}{l}\text { Memiliki teman } \\
\text { dekat untuk } \\
\text { berbagi cerita }\end{array}$ & Tercapai \\
\hline $\begin{array}{l}\text { Memulai } \\
\text { interaksi }\end{array}$ & $\begin{array}{l}\text { Tidak mau } \\
\text { memulai } \\
\text { pembicaraan } \\
\text { dengan orang lain }\end{array}$ & 0 & 0 & 0 & 0 & 0 & 1 & $\begin{array}{l}\text { Tidak mau } \\
\text { memulai } \\
\text { pembicaraan } \\
\text { dengan orang lain }\end{array}$ & $\begin{array}{l}\text { Tidak } \\
\text { Tercapai }\end{array}$ \\
\hline
\end{tabular}




\section{Pembahasan}

Intervensi yang diberikan yakni latihan keterampilan sosial untuk Subjek. Pemberian psikoedukasi kepada keluarga merupakan penunjang untuk mencegah relaps pada Subjek. Ditinjau dari penyebab relaps Subjek adalah karena ketidakteraturan minum obat, maka psikoedukasi pada keluarga sangat penting dilakukan. Dalam kasus ini, Subjek sebenarnya memiliki kesadaran yang baik terhadap kepatuhan minum obat, namun demikian, ketika obat habis, Subjek maupun keluarga tidak melakukan kontrol ke RSJ, sehingga membuat Subjek mengalami putus obat. Dukungan keluarga sangat penting bagi kepatuhan dan keteraturan minum obat terlebih dalam melakukan kontrol obat sehingga dapat menurunkan kemungkin Subjek relaps kembali (Pelealu \& Wowiling, 2018). Ketidakteraturan minum obat ini dikarenakan keluarga Subjek yang tidak memiliki biaya untuk pergi kontrol ke RSJ. Padahal dukungan keluarga baik secara materil ataupun non materil sangat berperan penting dalam kesembuhan Subjek. Oleh karena itu kesadaran tentang bahaya putus obat perlu ditingkatkan pada keluarga Subjek sehingga keluarga tetap mengusahakan untuk melakukan kontrol ke RSJ.

Intervensi latihan keterampilan sosial sesuai dengan masalah Subjek karena mengajarkan beberapa hal yang sesuai dengan perilaku maladaptif Subjek saat ini, yakni gangguan skizofrenia dengan permasalahan rendahnya interaksi sosial. Intervensi diberikan melalui praktik sederhana yang dapat dipahami oleh Subjek dengan baik dan diberikan secara bertahap. Latihan keterampilan sosial pada skizofrenia mengajarkan individu untuk memiliki kemampuan yang lebih baik dalam mengorganisasi usaha mental, seperti inisiasi dan mengatur rencana perilaku (Bellack et al., 2013). Individu diberikan keterampilan untuk melakukan interaksi sosial seperti non verbal (kontak mata, senyum, posisi tubuh tegap), serta kemampuan verbal, seperti berkenalan dan menyapa dengan perintah, maupun berkenalan dan menyapa tanpa perintah (inisiatif).

Subjek memiliki motivasi yang progresif dari awal sesi hingga pada akhir sesi. Subjek dapat mengutarakan secara mandiri tentang manfaat dari melakukan pelatihan keterampilan sosial pada saat evaluasi. Subjek juga dapat menyimpulkan tentang hal yang harus dilakukan kedepannya termasuk kepatuhan minum obat. Motivasi Subjek menjadi hal yang sangat penting dalam keberhasilan intervensi. Keberhasilan intervensi keterampilan sosial berhubungan dengan kesadaran Subjek bahwa Subjek membutuhkan intervensi untuk mempelajari suatu keterampilan yang telah dipikirkannya. Motivasi adalah kunci penentu keberhasilan intervensi dengan meningkatkan pengetahuan individu tentang target perilaku yang dituju (Medalia \& Saperstein, 2011).

Namun demikian, agar hasil intervensi semakin baik, maka pembiasaan keterampilan sosial ini perlu ditingkatkan sehingga Subjek memiliki kebiasaan yang baik dalam melakukan interaksi sosial. Oleh karena itu dukungan keluarga menjadi hal yang penting juga untuk keberhasilan intervensi. Subjek memiliki interaksi sosial yang rendah akibat dari pembiaran yang dilakukan oleh lingkungan Subjek dalam melakukan interaksi sosial. Selain itu, Subjek juga memiliki modelling yang kurang dari lingkungannya, dalam hal ini terutama ayahnya yang sibuk bekerja di sawah, terlebih setelah pulang dari sawah, ayah Subjek langsung istirahat di rumah dan jarang berkumpul dengan tetangga. Ayah Subjek juga membiarkan Subjek terbiasa dengan kegiatannya yakni mengurung diri dan tidak melakukan interaksi sosial dengan tetangganya. Hasil dari individu yang memiliki perilaku maladaptif adalah akibat dari modelling yang salah yang telah dilihatnya, serta dengan adanya pembentukan perilaku akibat pembiaran (tidak adanya penguatan maupun hukuman terhadap perilaku yang ditunjukkan oleh individu) (Kerig, 2011). Kebiasaan rendahnya interaksi sosial terpola dan menjadi semakin buruk, dapat pula diartikan menjadi kebiasaan yang dibenarkan oleh Subjek sehingga dilakukan secara terus-menerus.

Terkait dengan putus obat yang dilakukan oleh Subjek, terapis telah menjelaskan tentang pentingnya menjaga keteraturan minum obat. Keluarga Subjek mengeluhkan bahwa Subjek 
seringkali sakit perut setelah minum obat, namun hal tersebut akan hilang ketika keluarga Subjek membawa Subjek ke mantra terdekat, padahal mantri hanya berpura-pura menyuntik Subjek. Dengan demikian, Subjek hanya beralasan sakit perut. Keluarga Subjek juga menghentikan pengobatan karena khawatir ginjal Subjek akan mengalami masalah, namun demikian telah dijelaskan oleh terapis bahwa obat yang diberikan oleh dokter adalah sudah sesuai dengan dosis atau ukuran yang aman bagi Subjek sehingga keluarga tidak perlu khawatir dengan dampak minum obat pada Subjek.

\section{Simpulan}

Latihan keterampilan sosial dapat meningkatkan interaksi sosial pada individu dengan skizofrenia. Interaksi sosial yang diajarkan meliputi keterampilan berkomunikasi secara verbal dan non verbal. Subjek mampu melakukan komunikasi non verbal dengan baik setelah adanya intervensi. Begitupula untuk komunikasi verbal, namun demikian, inisiatif dalam memulai komunikasi verbal perlu untuk ditingkatkan dengan adanya latihan keterampilan dan pembiasaan selanjutnya agar dapat diaplikasikan dalam kehidupan sehari-hari oleh Subjek. Selain itu, keluarga telah diberikan edukasi tentang pentingnya minum obat sehingga tidak lagi terjadi putus obat yang menyebabkan Subjek kembali masuk rumah sakit jiwa.

\section{Referensi}

Alwisol, M. (2011). Psikologi kepribadian. Malang: Universitas Muhammyadiah Malang.

Arif, I. S. (2006). Skizofrenia: memahami dinamika keluarga. Rose Herlina. Bandung: PT. Refika Aditama.

APA. (2013). Diagnostic and statistical manual of mental disorders (DSM-5®). American Psychiatric Pub.

Bellack, A. S., Mueser, K. T., Gingerich, S., \& Agresta, J. (2013). Social skills training for schizophrenia: A step-by-step guide. New York: Guilford Publications.

Burns, R. C. (2014). Kinetic house-tree-person drawings: khtp: an interpretative manual. Routledge.

Gilbert, Joseph. (1978). Interpreting psychological test data. USA: Litton Educational Publishing. Inc.

Kaplan, H. I., Sadock, B. J., \& Grebb, J. A. (2010). Sinopsis psikiatri: Ilmu pengetahuan perilaku psikiatri klinis. Jakarta: Bina Rupa Aksara.

Kerig, P. K. (2011). Models of Psychopathology. Encyclopedia of Adolescence. Elsevier Inc.

Kneisl, C. R., \& Trigoboff, E. (2004). Contemporary psychiatric-mental health nursing. Pearson/Prentice Hall. Little, S. G., Swangler, J., \& Akin-little, A. (2017). Handbook of social behavior and skills in children. Handbook of Social Behavior and Skills in Children, Autism and Child Psychopathology, 9-17. https://doi.org/10.1007/978-3-319-64592-6

Maslim, R. (2001). Buku saku diagnosis gangguan jiwa rujukan ringkas dari PPDGJ-III. Jakarta: Bagian Ilmu Kedokteran Jiwa FK Unika Atma Jaya.

Medalia, A., \& Saperstein, A. (2011). The role of motivation for treatment success. Schizophrenia Bulletin, 37(suppl_2), S122-S128.

Myin-Germeys, I., van Os, J., Schwartz, J. E., Stone, A. A., \& Delespaul, P. A. (2001). Emotional reactivity to daily life stress in psychosis. Archives of General Psychiatry, 58(12), 1137-1144.

Olson, M. H., \& Hergenhahn, B. R. (2011). Pengantar teori-teori kepribadian. Yogyakarta: Pustaka Pelajar.

Pelealu, A., \& Wowiling, F. (2018). Hubungan dukungan keluarga dengan kepatuhan minum obat pasien skizofrenia di rumah sakit jiwa Prof. DR.V.L. Ratymbuysang Provinsi Sulawesi Utara. E-Journal Keperawatan, 6(1).

Prawitasari, J. E., Noor Rochan Hadjam, M., Atamimi, N., Retnowati, S., Sofiati Utami, M., Ramdhani, N., \& Ul Hasanat, N. (2002). Psikoterapi, pendekatan konvensional dan kontemporer. Yogyakarta: Unit Publikasi Fakultas Psikologi UGM.

Renidayati, Nurjanah S., Rosiana A., Rosiana A.,Pinilih S. (2015). Modul keterampilan sosial (social skill training). Depok: Universitas Indonesia Press.

Rus-Calafell, M., Gutiérrez-Maldonado, J., Ribas-Sabaté, J., \& Lemos-Giráldez, S. (2014). Social skills training for people with schizophrenia: what do we train?. Psicología Conductual, 22(3), 461.

Varcarolis, E. M., Carson, V. B., \& Shoemaker, N. C. (2006). Foundations of psychiatric mental health nursing 5th ed. St. Louis Missouri: Saunders Elsevier. 